\title{
Are Prospective EFL Teachers Culturalist or Interculturalist?
}

\author{
Dincay Koksal ${ }^{1} \&$ Gulten Genc ${ }^{2}$ \\ ${ }^{1}$ Department of Foreign Language Education, Faculty of Education, Çanakkale Onsekiz Mart University, \\ Çanakkale, Turkey \\ ${ }^{2}$ Department of Foreign Language Education, Faculty of Education, İnönü University, Malatya, Turkey \\ Correspondence: Gulten Genc, Faculty of Education, Block A, No: 30, İnönü University, 44280, \\ Kampus/Malatya, Turkey. E-mail: gulten.genc@inonu.edu.tr
}

Received: March 10, 2020 Accepted: May 1, 2020 Online Published: May 28, 2020

doi:10.5539/jel.v9n3p143 URL: https://doi.org/10.5539/jel.v9n3p143

\begin{abstract}
The research aimed to investigate the current cultural stance and the attitudes of prospective EFL teachers towards culture teaching. For this purpose, 200 teacher candidates (73 males 127 females) studying at a teacher training program of a state university were involved in the study. A demographic information form and two questionnaires were used to collect the data. The participants' cultural intelligence profile was assessed under four sub-dimensions. Statistical analyses such as descriptive statistics, independent samples T-tests, Pearson Correlations, and ANOVA were used in analyzing the quantitative data. According to the results of the study, EFL student teachers had positive attitudes towards teaching culture in foreign language classes. They were also seen to have varying degrees of cultural intelligence. As for the effect of gender, age, and the year of the study at the faculty, the analyses revealed that gender and age were not related significantly to the attitudes towards culture teaching and cultural intelligence. The year of the study at the faculty seemed to have a significant relationship with the attitudes towards culture teaching and cultural intelligence. The last two years of undergraduate study at the ELT departments were seen to be significant on prospective EFL teachers' culturalist or interculturalist stances. Finally, the researchers discovered a positive relationship between prospective teachers' attitudes towards culture teaching and their meta-cognitive, motivational, and behavioral dimensions of cultural intelligence. Some recommendations were presented for future researchers and practitioners relying on the research findings.
\end{abstract}

Keywords: teaching culture in ELT, cultural intelligence, EFL teacher education, language teaching, intercultural education

\section{Introduction}

It has long been accepted that foreign language learners might not truly master the language without learning about its culture since the language is the primary tool for communication and interaction in societies. Ardila-Rey (2008, p. 335) stated, "Language and culture are inextricably linked with each other." Only mastering the grammar of the language has never guaranteed to communicate in that language. The crucial importance of learning culture in language learning has been emphasized by Kramsch (1993), who stated, "language teaching consists of teaching the four skills plus culture." It is possible to see many studies in the literature indicating and emphasizing the importance of culture in language teaching as well as the close relationship between them (Kramsch, 1998; Tang, 1999; Savignon \& Sysoyev, 2005; Schulz, 2007; Brown, 2007; Kuang, 2007). The close and interwoven relationship between language and culture has also been underscored by Wardhaugh (2010) and Eastman (1980), pointing out that how the speakers of a language see the world is mainly shaped by the structure of the language they speak.

\subsection{Culture Teaching in ELT: From Culturalism to Interculturalism}

Culture teaching as an essential part of second language teaching is undoubtedly not a new issue, and it has been studied and discussed by many different researchers such as Atkinson (1999), Brown and Eisterhold (2004), Brown (2007), and Tang (2006). The literature review revealed that different approaches and methods of language teaching emphasize the integration of culture in language teaching. As emphasized traditionally, cultural aspects of the languages were supposed to be taught concurrently with the linguistic aspects. Besides, foreign language teachers were strongly recommended to set goals to teach culture in their classrooms (Valette, 
1986). According to Valetta (1986), those goals were gathered under four categories as; developing awareness about the target culture, teaching the etiquette of the target culture, becoming aware of the differences between the self and target culture, and finally being familiar with the values of the target culture.

Culture incorporated language teaching is as old as the grammar-translation method in which culture was taught as "high culture" through literature and fine arts. Long (2001) claimed that through the Grammar-Translation Method, culture was emphasized by comparing various aspects of languages while translating. Additionally, using the Latin dialogues was providing extracts for the learners to study Latin culture as well as the language. However, studying only "high culture" was accepted adequate for the learners of that age since they did not have the opportunity to contact with the speakers of the target language, namely Latin.

After the adoption of Direct Method and Audiolingualism, language teachers were expected to teach culture in the form of daily behavior and the lifestyles of the societies of the target language (TezCultteach2). In Direct Method, culture was expected to be taught as the history and the geography of the target societies (Larsen-Freeman, 2000), whereas in the Audio-lingual Method, drills involved issues and cultural traces from everyday life of American people (Grittner, 1990).

In the Designer Methods of the Humanistic Approach, namely the Silent Way, Community Language Learning, and Suggestopedia, culture teaching was not neglected. According to Larsen-Freeman (2000), in these three language teaching methods, culture is reflected in everyday life and expected to be studied as a part of the language in the form of style, art, literature, customs, and habits. In suggestopedia, the teaching materials were mainly the music, games, and puzzles taken from the target language and indeed carried the cultural components of the target community.

In the 1970s, the introduction of Communicative Language Teaching shifted attention to Halliday's (1973) "functions of language" and Hymes' (1972) "communicative competence" and a new perspective to culture teaching, accordingly. Competence in a foreign language, in a sense, required an understanding of the beliefs, traditions, and values of the target cultures. In other words, learning to communicate in English as a second language means also learning how to function in a new culture. This new concept of communicative competence involved Noam Chomsky's linguistic competence and went beyond it by involving real communicative experiences. Canale and Swain revolutionized the language teaching by redefining the "communicative competence" and expanding it as a multidimensional concept as follows;

- Linguistic competence involving the linguistics aspect of languages such as grammatical and semantic rules and lexical items.

- Discourse competence enables speakers to combine the form and meaning to reach a meaningful unity of spoken and written texts. Repetition, organization of meaning, and relevance of ideas are all related to discourse competence.

- Pragmatic competence enables second language speakers to create and interpret discourse. It has been defined as the ability to use acceptable language functions and utterances appropriate in a particular context.

- Sociolinguistic competence primarily defines the knowledge of rules and conventions underlying the appropriate language use in different social settings such as formality and directness.

- Strategic competence indicates the acquisition of verbal and non-verbal communication strategies to avoid and repair communication breakdowns and to communicate effectively in unfamiliar situations.

Nowadays, globalization led English gradually become the language for international communication and redefined the goals and cultural aspects of English language teaching. As argued by Atay et al. (2009), the goal of language teaching is no longer possible to be limited by the just acquisition of communicative competence in the target language. Wandel (2003) claimed that since English has gained a new role as the world language, a shift towards the cultural aspect of language teaching will be indispensable and added that culture teaching must go beyond the culture of the countries where English is the first language such as the USA, UK, and Canada. Thus, Wandel (2003) emphasized enhancing the cultural awareness and cultural sensitivity of foreign language learners. Alptekin (2002) also claimed that learners need to develop intercultural communicative competence to communicate and function effectively in a multi-cultural world. The Council of Europe (2001) defined culturally competent learners as the ones having sociolinguistic competence, pragmatic competence, sociocultural knowledge, and intercultural awareness as well as grammatical competence.

In 1997, Byram defined the communicative competence in terms of sociolinguistics norms and intercultural communication competence by emphasizing a need for intercultural understanding in foreign language teaching. Byram (1997) designed a model for intercultural competence with five different dimensions as Knowledge, 
Attitudes, Skills of interpreting and relating, Skills of discovery and interaction, and Political education, including critical cultural awareness. According to his model, knowledge is related to the social life and practices of the societies, whereas attitudes are related to developing tolerance and positive feelings towards differences and cultural values of other societies. Skills of interpreting and relating involve adopting different cultural perspectives and being flexible to be able to function smoothly in different cultural settings. Skills of discovery and interaction involve the ability to communicate effectively in real-life conditions and acting culturally responsive in different cultural contexts. Lastly, critical cultural awareness could be defined as having the necessary skills to critically evaluate one's own and other cultural components.

\subsection{Cultural Intelligence ( $C Q)$}

Cultural intelligence (CQ) has recently been studied by researchers in various fields, such as leadership, business, and language education. It could be defined as the ability to behave appropriately in different cultural contexts (Earley \& Ang, 2003). Thus, it could be accepted that a high level of cultural intelligence enables individuals to cope with the challenges caused by intercultural settings.

Cultural intelligence involves four main factors as cognitive, metacognitive, motivational, and behavioral. Cognitive cultural intelligence enables the individuals the appreciation of the differences and similarities between different cultures. A high level of cognitive CQ indicates knowledge of other cultures such as political and economic systems, languages, values, and religions and respect for the differences (Brislin, Worthley, \& Macnab, 2006). Metacognitive cultural intelligence is related to the mental processes used by individuals to understand the differences in the values and cultures of the communities. A high level of metacognitive CQ enables individuals to adopt appropriate mental models while interacting with people from different cultural backgrounds (Ang et al., 2007). Motivational cultural intelligence involves the desire, interest, and energy of individuals towards intercultural adaptation (Livermore, 2010). It arouses the curiosity of individuals to learn about culturally different places ( $\mathrm{Ng}$ et al., 2012). As the last component of cultural intelligence, behavioral cultural intelligence involves both verbal and nonverbal actions of individuals in intercultural settings (Ang et al., 2007). A high level of behavioral cultural intelligence enables individuals to act appropriately in a different cultural context.

\subsection{Research Questions}

As can be seen above, the place of culture in foreign language teaching has shifted notably from "emphasis on literature, the arts and philosophy to culture as a shared way of life" (Byram, 1997). However, in today's ever-changing world, it is difficult to refer to a specific culture or target culture in language teaching, while languages are used in the intercultural setting without cultural boundaries. As a result, the recent popular question, "whose culture to teach" (Damen, 1987, p. 213), came to the fore. Thus, the study was designed to uncover the perspectives of prospective EFL teachers about culture teaching and intercultural education. Thus, the research questions of the study could be presented as follows;

1) What is the current stance of prospective EFL teachers in terms of culture teaching and cultural intelligence?

2) Does their stance differ in terms of age, gender, and department?

\section{Method}

\subsection{Participants and Setting}

This study was carried out at a state university in the eastern part of Turkey. The prospective teachers in the undergraduate ELT program are admitted to the department after a central exam conducted throughout the country by the Higher Educational Council. The courses, which last eight semesters, offered at the foreign language education department include the Methodology Courses, School Experience, and Practice Teaching in TEFL (Teaching English as a Foreign Language). Besides those non-elective courses, they are expected to receive some elective courses related to TEFL. Culture teaching and intercultural education are mostly handled as an integrated part of the main courses. Also, in the department, explicit culture teaching courses such as "Intercultural Communication" and "Language and Culture" are accessible as elective courses. The department of foreign language education where the study was conducted has been training prospective English teachers since the 1999-2000 academic year.

A total number of 200 students participated in the study. The participants were non-native Turkish speakers of English. Of the students, 73 (36.5\%) were male, and 127 (63.5\%) were female. Participants' age ranged from 18 to 37 , with a mean of 21 . Of the participants, $43(21.5 \%)$ were freshmen, $52(26.9 \%)$ were sophomores, 53 $(26.5 \%)$ were juniors, and finally $52(52 \%)$ were seniors. 


\subsection{Data Collection Tools}

In the study, a background information form, investigating the demographic information, such as age, gender, and year of the study, of the participants and two questionnaires were used. A questionnaire involving 13 items was used to determine the attitudes of the participants. The questionnaire was developed by Sarıçoban and Çalışkan (2011). The Cronbach Alpha Coefficient value of the questionnaire was found to be .875 for the study. The second questionnaire used in the study was the Cultural Intelligence Scale (Cultural Intelligence Center, 2005), which consisted of 20 items and four sub-dimensions as metacognitive cultural intelligence, cognitive cultural intelligence, motivational cultural intelligence, and behavioral cultural intelligence. The questionnaire was adapted to Turkish by İlhan and Çetin (2014). The Cronbach Alpha Coefficient value of the Cultural Intelligence Scale was determined as .875 , which is quite reliable to conduct the study. The scale consisted of 4 components, and the reliability coefficients of four sub-dimensions were respectively identified as follows: metacognitive cultural intelligence, .860; cognitive cultural intelligence, .868; motivational cultural Intelligence, .846; and behavioral cultural intelligence, .801 .

\subsection{Data Analysis}

To answer the research questions of the study, descriptive and inferential analyses were conducted by using the Statistical Package for Social Sciences (SPSS) program. After confirming the data distribution in scales, independent samples t-test, variance analysis, and correlation analysis were chosen from amongst the parametric test techniques to test the research questions of the study.

\section{Findings and Discussion}

1) What is the current stance of prospective EFL teachers in terms of culture teaching and cultural intelligence?

Descriptive statistics were conducted, and the results were revealed in the following table (Table 1) to determine the cultural and intercultural stance of the participants in language teaching. The questionnaire tended to determine the attitudes of prospective EFL learners towards the role of the target culture in ELT setting.

The first item of the questionnaire was supported by $75.5 \%$ of the participants with a mean of 3.58 , indicating that those participants readily agreed on adopting culture teaching objectives besides linguistic goals in ELT classes. Of the participants, $77 \%$ of them reported that they did not hold the belief that learning a foreign culture would harm the native culture, whereas $74 \%$ of the participants reflected their desire to learn the target culture. However, around one fifth $(18+7.5 \%)$ of the participants did not reveal the willingness to learn the target culture. A tremendous amount of participants $(71 \%)$ did not agree with the idea that "EFL teachers should focus only on the teaching of language, not culture." Nevertheless, $18 \%$ of them seemed to agree with this idea, while $11 \%$ of them were neutral. The proportion of the participants reflecting their negative attitudes towards culture teaching cannot be underestimated.

Similarly, $71 \%$ of the participants agreed to involve cultural elements in the foreign language teaching curriculum, while $17.5 \%$ did not seem to have any idea, and $11 \%$ reported disagreement. Though more than half of the participants (63.5\%) rejected leaving out English/American culture from ELT syllabi, around one fifth reported the agreement, and the rest (18.5\%) seemed to be neutral. The responses showed that a significant proportion of $(77.5 \%)$ the participants shared the opinion that learning cultural components fosters proficiency in the target language. The majority of prospective teachers $(83.5 \%)$ endorsed that EFL teachers should be well equipped with the cultural patterns of the language they teach. The teacher candidates' preferences related to this item indicate that even if they all do not show much willingness to teach culture in language classes, they believe that language teachers should have sufficient knowledge about the target culture. More than half of the participants (56.5\%) did not agree with the opinion that they did not need knowledge of British/American culture while teaching English. Besides, one-fourth of them did not express their opinion, and almost one fifth (17.5\%), consistent with their responses to the other items in the scale, reported that English could be taught without referencing target culture (Table 1). 
Table 1. Prospective teachers' responses to culture teaching in language classes

\begin{tabular}{|c|c|c|c|c|c|}
\hline & $1+2(\%)$ & $3(\%)$ & $4+5(\%)$ & Mean & SD \\
\hline $\begin{array}{l}\text { "EFL teachers should have culture teaching objectives in addition to } \\
\text { linguistic goals". }\end{array}$ & 8.5 & 16.5 & 75.5 & 3.58 & 0.86 \\
\hline "Learning a foreign culture harms the native culture". & 77.0 & 11.5 & 11.5 & 3.54 & 0.97 \\
\hline "I should learn about target culture". & 7.5 & 18.5 & 74 & 3.59 & 0.84 \\
\hline $\begin{array}{l}\text { "EFL teachers should focus only on the teaching of language, not } \\
\text { culture". }\end{array}$ & 71.0 & 11.0 & 18.0 & 3.35 & 1.14 \\
\hline $\begin{array}{l}\text { "Cultural content is an element of the foreign language teaching } \\
\text { curriculum". }\end{array}$ & 11.0 & 17.5 & 71.5 & 3.49 & 0.95 \\
\hline "EFL content should exclude English/ American culture". & 63.5 & 18.5 & 18.0 & 3.27 & 1.13 \\
\hline $\begin{array}{l}\text { "Learning cultural components explicitly fosters our proficiency in the } \\
\text { language". }\end{array}$ & 6.5 & 16.0 & 77.5 & 3.64 & 0.78 \\
\hline $\begin{array}{l}\text { "EFL teachers should be well equipped with cultural patterns of the } \\
\text { language they teach". }\end{array}$ & 7.0 & 9.5 & 83.5 & 3.69 & 0.79 \\
\hline "English can be taught without reference to British/American culture". & 56.5 & 26.0 & 17.5 & 3.21 & 1.10 \\
\hline $\begin{array}{l}\text { "Learning the cultural elements of the target language should be a must } \\
\text { for the learners". }\end{array}$ & 27.5 & 37.0 & 35.5 & 2.80 & 1.19 \\
\hline "I find it unnecessary to learn the British/ American culture". & 74.0 & 15.5 & 10.5 & 3.53 & 0.93 \\
\hline $\begin{array}{l}\text { "I feel uncomfortable when a question on foreign language culture is } \\
\text { asked in the classroom." }\end{array}$ & 47.5 & 34.5 & 18.0 & 3.11 & 1.08 \\
\hline $\begin{array}{l}\text { "Learning about British/American history helps us improve our language } \\
\text { skills." }\end{array}$ & 11.5 & 25.5 & 63.0 & 3.40 & 0.96 \\
\hline
\end{tabular}

Note. 5-Strongly agree, 4-Agree, 3-Neutral, 2-disagree, 1-strongly disagree.

Regarding the item suggesting that cultural elements must be a requirement in learning foreign languages, only $35 \%$ of the prospective teachers were seen to agree. Almost one-third of the participants did not agree with this idea, whereas $37 \%$ of them were neutral. The drop in the agreement rate of the participants is significant since it indicates that despite the positive attitudes prospective teachers have towards culture teaching, they do not believe that it must be a requirement in language teaching. As can be seen in the high disagreement level (74\%) of the participants in the item that "I find it unnecessary to learn the British/American culture," it could be said that participants give value to and are aware of the role of learning and teaching the British/American culture in foreign language classes, but they take a stand against this being an obligation. When confronting a question about foreign culture, almost half of the participants (47.5\%) uttered that they did not feel unrest.

Interestingly, over one-third of the participants responded that they did not have any idea related to these situations. The reason for not feeling comfortable in encountering a question about target culture might arise due to the lack of sufficient knowledge about it. As suggested by Damen (1987), teachers also had some limitations in efficiency as cultural guides since they did not know what exactly culture was and how to teach it. Although teachers' efficiency in culture teaching is beyond the scope of this research, it should be noted here that teachers' feeling of efficiency will enhance their confidence and foster positive attitudes about target culture accordingly. Finally, $63 \%$ of the participants seemed to hold a positive attitude towards learning more about target culture and agreed that learning about British/American history helps them improve their language skills (Table 1). The proportions of participants and the high consistency between the responses of related items indicated that participants mostly had positive attitudes towards teaching culture in language classes.

When the mean scores were taken into consideration, it could be explicitly seen that they were quite high in each of the items. High mean scores would be significant indicators of participants' awareness of and positive attitudes towards teaching target culture in language classes. In this context, it would not be awkward to voice that participants tend to adopt a culturalist approach in which the significance of target culture in language teaching was appreciated. The participants' tendency to adopt a culturalist perspective and being conservative about teaching target culture in foreign language classes appeared to be compatible with the literature. Kramsch (1991) pointed out that foreign language teachers in the USA gave priority to teaching the culture of the target language while teaching a foreign language. Studies conducted with native English-speaking teachers (Stapleton, 2000) and Finland-Swedish teachers of English (Larzén-Östermark, 2008) indicated teachers' culturalist approach with strong and positive attitudes towards teaching target culture.

When the responses of participants were contrasted, it was seen that although the majority of participants embraced incorporating cultural components into language teaching eagerly, they were cautious towards 
teaching only British and American culture. This caution could be due to the global position of English.

The cultural intelligence of the participants was also assessed to get an in-depth understanding and contrastive profile of participants' culturalist or interculturalist approaches. As for cultural intelligence, the frequency of participants' responses in percentages and means in each sub-dimension of cultural intelligence, in other words, their ability to behave effectively in different cultural contexts (Earley \& Ang, 2003), were illustrated in Table 2.

Table 2. Overall scores of cultural intelligence

\begin{tabular}{llll}
\hline Items & $\mathrm{N}$ & Mean & $\mathrm{SD}$ \\
\hline Metacognitive Awareness & 200 & 5.27 & 1.22 \\
Motivational Awareness & 200 & 5.25 & 1.24 \\
Behavioural Awareness & 200 & 5.04 & 1.16 \\
Cognitive Awareness & 200 & 4.53 & 1.21 \\
\hline
\end{tabular}

Overall mean scores of participants in all sub-dimensions of cultural intelligence were found slightly over 5.00 except for cognitive cultural intelligence. Since cultural intelligence was a seven-point Likert type scale, the scores around 5 indicated a moderately high level of cultural intelligence. It means that participants had relatively high metacognitive, cognitive, and behavioral types of intelligence, whereas they had a moderate level of cognitive intelligence (Table 2). These scores indicated that participants of English teacher training programs developed cultural intelligence skills to a certain extent due to possible interaction with the foreign culture through the years they spent at the faculty and multi-cultural materials used in this process. Hence, these scores were not surprising since those participants were familiar with the norms, beliefs, and daily lives of other cultures.

Prospective teachers had the highest scores in metacognitive and motivational aspects of cultural intelligence. High metacognitive intelligence indicated a high level of awareness and consciousness about both home culture and cross-cultural interactions (Ang et al., 2007). The high motivational cultural intelligence of the participants involved their desire and interest in adapting to the intercultural settings (Livermore, 2010). High motivational intelligence pushes individuals to learn and experience various cultures. The third highest intelligence was the behavioral intelligence which suggested that participants were good at using appropriate verbal and nonverbal actions during interaction with people from different cultures (Ang et al., 2007). The lowest intelligence type was cognitive intelligence, which revealed that participants did not have sufficient knowledge about the basic framework, similarities, and differences of various cultural values (Hofstede, 2001). Participants got the lowest scores in the items of cognitive intelligence, investigating the cultural values and religious beliefs, the arts and crafts, and the marriage systems of the other cultures. In other words, those items were mainly about the social and daily life of other cultures, which might require being experienced in societies. So, low cognitive intelligence might be due to the lack of inexperience in sharing a social life with culturally diverse people.

Table 3. Correlations between attitudes towards culture teaching and cultural intelligence

\begin{tabular}{llll}
\hline Items & r & p & N \\
\hline Meta-cognitive Intelligence & 0.457 & 0.00 & 200 \\
Cognitive Intelligence & 0.154 & 0.30 & 200 \\
Motivational Intelligence & 0.469 & 0.00 & 200 \\
Behavioural Intelligence & 0.290 & 0.00 & 200 \\
\hline
\end{tabular}

Lastly, Pearson R correlations were conducted to assess if relationships exist between prospective teachers' attitudes towards culture teaching and the four cultural intelligence scores. As can be seen in Table 6, the study indicated significant positive correlations between the attitudes of the participants towards culture teaching and their meta-cognitive, motivational, and behavioral types of cultural intelligence. In a positive relationship, two of the variables increase or decrease together. A Pearson $\mathrm{R}$ correlation is a bivariate measure of association that detects the strength of the relationship between the variables. Thus, the strength of the relationship was assessed, as well. It was seen that the correlation between attitudes and two types of cultural intelligence, namely meta-cognitive and motivational intelligence types, is relatively high and robust, whereas the correlation between behavioral intelligence is at a moderate level. Cognitive intelligence was not seen to be correlated with the attitudes of the participants towards culture teaching. The most robust relationship was found between 
motivational intelligence and attitudes. This result was not surprising for the researchers since the positive attitudes towards culture teaching would result in strong motivation and curiosity about learning the foreign culture or vice versa.

Similarly, metacognitive intelligence was another subscale positively and strongly correlated with attitudes of participants towards culture teaching. It indicated that the higher the awareness and conscious levels of participants about cultural issues, the stronger their positive attitudes were. The participants received the lowest mean scores on behavioral and cognitive intelligence types (Tables 3 and 5), and the correlations between these two types of intelligence and their attitudes towards culture teaching were either weak or insignificant, correspondingly. This finding was thought to be quite striking with regards to indicating the close relationship between having positive attitudes towards culture teaching, namely being culturalist, and high levels of cultural intelligence or being interculturalist. They could have positive attitudes towards teaching the target culture and the intercultural components once they developed awareness, motivation, curiosity, and consciousness of other cultures and cultural differences.

In addition to the correlation analysis, when the mean scores of the items of the attitudes towards the culture teaching scale and of the subscales in the cultural intelligence scale were considered, the similarities between the results could easily be realized (Tables 1 throug 6). Mean scores of attitudes towards culture teaching scale correspond to those of cultural intelligence. In other words, since the "Attitudes towards the Culture Teaching Scale" was a five-point Likert type scale, the scores around 3.50 indicated a moderately high level of (positive) attitudes. So, it became difficult to decide if the participants were culturalist or interculturalist alone. It was also seen that participants were under the influence of both approaches as culturalist and interculturalist to a certain extent.

2) Does their stance differ in terms of age, gender, and department?

Since the study was designed to examine the effect of gender, age, and year of the study, t-test, Pearson Correlation, and ANOVA were performed. Firstly, the effect of gender was analyzed and found out that there was not a significant effect of gender on the participants' attitudes towards culture teaching in ELT classes and the dimensions of cultural intelligence.

Table 4. Attitudes towards culture teaching and cultural intelligence in terms of gender

\begin{tabular}{lllllll}
\hline Items & & $\mathrm{N}$ & Mean & Std. D. & $\mathrm{t} / \mathrm{F}^{*}$ & $\mathrm{P}$ \\
\hline Attitudes towards culture teaching & Female & 127 & 1.54 & 0.54 & 1.495 & 0.62 \\
& Male & 73 & 1.50 & 0.50 & & \\
Meta-cognitive Intelligence & Female & 127 & 5.27 & 1.20 & -0.10 & 0.92 \\
& Male & 73 & 5.22 & 1.15 & & \\
Cognitive Intelligence & Female & 127 & 4.59 & 1.15 & 0.84 & 0.42 \\
& Male & 73 & 4.44 & 1.30 & & \\
Motivational Intelligence & Female & 127 & 5.30 & 1.21 & 0.73 & 0.46 \\
& Male & 73 & 5.16 & 1.29 & & \\
Behavioural Intelligence & Female & 127 & 5.13 & 1.12 & \multirow{2}{*}{1.46} & 0.14 \\
& Male & 73 & 4.88 & 1.22 & & \\
\hline
\end{tabular}

Secondly, the effect of age was analyzed, and as can be seen in Table 5, it was not found to be an effective factor in attitudes towards culture teaching and any dimensions of cultural intelligence.

Table 5. Attitudes towards culture teaching and cultural intelligence in terms of age

\begin{tabular}{llll}
\hline & r & p & N \\
\hline Attitudes towards culture teaching & -0.51 & 0.47 & 200 \\
Meta-cognitive Intelligence & 0.94 & 0.18 & 200 \\
Cognitive Intelligence & 0.10 & 0.14 & 200 \\
Motivational Intelligence & -0.42 & 0.55 & 200 \\
Behavioural Intelligence & 0.15 & 0.02 & 200 \\
\hline
\end{tabular}

Finally, the effect of participants' year of the study was analyzed, and the results of ANOVA indicated a significant difference between the year of the study and attitudes towards culture teaching as well as the four 
dimensions of cultural intelligence, as presented in Table 6. Post Hoc Tukey HSD analysis was carried out to find out which group created the difference.

Table 6. Attitudes towards culture teaching and cultural intelligence in terms of participants' year of the study

\begin{tabular}{|c|c|c|c|c|c|c|c|}
\hline & & Sum of Squares & Df & Mean Square & $\mathrm{F}$ & Sig. & Stat. Dif \\
\hline \multirow{3}{*}{$\begin{array}{l}\text { Attitudes towards culture } \\
\text { teaching }\end{array}$} & Between Groups & 6.39 & 3 & 2.13 & \multirow[t]{3}{*}{9.62} & \multirow[t]{3}{*}{0.00} & \multirow[t]{3}{*}{$4 *$} \\
\hline & Within Groups & 43.421 & 196 & 0.22 & & & \\
\hline & Total & 49.820 & 199 & & & & \\
\hline Meta-cognitive & Between Groups & 14.607 & 3 & 4.86 & \multirow[t]{3}{*}{3.37} & \multirow[t]{3}{*}{0.01} & \multirow[t]{3}{*}{$4 *$} \\
\hline \multirow[t]{2}{*}{ Intelligence } & Within Groups & 282.69 & 196 & 1.44 & & & \\
\hline & Total & 297.3 & 199 & & & & \\
\hline \multirow[t]{3}{*}{ Cognitive Intelligence } & Between Groups & 26.351 & 3 & 8.78 & \multirow[t]{3}{*}{6.49} & \multirow[t]{3}{*}{$0.00 *$} & \multirow[t]{3}{*}{$3 *$} \\
\hline & Within Groups & 265.133 & 196 & 1.35 & & & \\
\hline & Total & 291.484 & 199 & & & & \\
\hline \multirow[t]{3}{*}{ Motivational Intelligence } & Between Groups & 52.281 & 3 & 17.42 & \multirow[t]{3}{*}{13.31} & \multirow[t]{3}{*}{$0.00 *$} & \multirow[t]{3}{*}{$3 *$} \\
\hline & Within Groups & 256.034 & 196 & 1.30 & & & \\
\hline & Total & 308.315 & 199 & & & & \\
\hline \multirow[t]{3}{*}{ Behavioural Intelligence } & Between Groups & 18.723 & 3 & 6.24 & \multirow[t]{3}{*}{4.86} & \multirow[t]{3}{*}{$0.00^{*}$} & \multirow[t]{3}{*}{$4^{*}$} \\
\hline & Within Groups & 251.370 & 196 & 1.28 & & & \\
\hline & Total & 270.093 & 199 & & & & \\
\hline
\end{tabular}

Note. $* \mathrm{P}<0.05$.

As can be seen in the table, the groups creating the difference in the analyses were the third and fourth-year prospective teachers. In the attitudes towards teaching culture, the group created the difference was the last year students. Similarly, in the meta-cognitive and behavioral intelligence sub-dimensions, the difference was created by the fourth-year students. However, in the cognitive and motivational intelligence sub-dimensions, the source of the difference was the third-year prospective teachers. These results reveal that towards the end of the teacher training program, participants were becoming more and more sensitive to culture teaching issues in foreign language classes.

Those results are thought to mean a lot in terms of the role of the teacher education process in developing cultural intelligence and positive attitudes towards culture teaching. The findings indicating that the fourth-year students had the highest scores in developing positive attitudes, metacognitive and behavioral intelligence types and the third-year students had the highest scores in cognitive and motivational intelligence types firstly emphasize the effective factors that can cultivate awareness and consciousness of participants towards cultural components and culture teaching. It was explicitly seen that participants in ELT departments would develop positive attitudes towards culture teaching and higher cultural intelligence with the help of some opportunities they would be offered at the faculty. Among those opportunities were interacting with the materials involving different cultures, using authentic materials, and interacting with foreigners from different cultural settings and even explicitly dealing with culture-related issues. Another striking finding determined in this analysis was the developmental sequence of cultural intelligence types of participants. Participants firstly developed cognitive and motivational intelligence, which means that they first develop a desire to learn about other cultures and increase their knowledge about them. Motivational intelligence could be called as the crucial step of becoming an interculturalist since it provokes the willingness and enthusiasm to be involved in other cultures and to cope with the confusing situations (Lin, Chen, \& Song, 2012). After becoming knowledgeable about other cultures, participants seem to be mentally ready to become interculturalist. In other words, they start to realize, understand, monitor, and appreciate the differences between the cultures and the societies accordingly by thinking about other cultures (Earley \& Ang, 2003). Finally, they become ready to behave appropriately in culturally diverse situations by adapting their behaviors (Van Dyne, Ang, \& Livermore, 2009). Participants are expected to perform well in both verbal and non-verbal actions in cross-cultural communications (Ang et al., 2007). As can be seen in this process, the participants are becoming interculturalist in time.

\section{Conclusion and Implications}

In conclusion, some major points could be noted in the research. First, it was concluded that prospective teachers tend to adopt a culturalist approach in which the significance of target culture in language teaching was appreciated. Their positive attitudes towards teaching cultural components indicated their willingness and enthusiasm about adopting the culturalist approach. Second, prospective teachers were seen to be best in 
metacognitive and motivational aspects of cultural intelligence. Namely, they were highly aware of their home culture as well as cross-cultural issues. They were also successful at using appropriate verbal and nonverbal actions in intercultural settings since they had a relatively higher level of behavioral intelligence. However, prospective teachers had the lowest scores in cognitive intelligence, which meant that they needed to learn more about the social and daily lives of other cultures. Third, the close relationship between having positive attitudes towards culture teaching, namely being culturalist, and high levels of cultural intelligence or being interculturalist was another striking conclusion of the study. It was also seen that once prospective teachers developed awareness, motivation, curiosity, and consciousness towards other cultures and cultural differences, they would undoubtedly develop positive attitudes towards teaching both the target culture and the intercultural components. Finally, the last two years of undergraduate study at the ELT departments have crucial importance in terms of prospective teachers' adoption of culturalist and interculturalist approaches. In the last two years, prospective teachers reflected the change in their perspectives in terms of cultural and intercultural issues. It could undoubtedly be the result of familiarization with the foreign cultures and exposure to some overt and covert culture-related issues during the years at the faculty. Thus, considering the effect of undergraduate education on prospective teachers' attitude formation and cultural intelligence development, this study should inform theoreticians and practitioners of the ELT field in their curricula formation processes. It should be kept in mind that EFL teacher training programs should offer proper training of cultural and intercultural components for prospective teachers to enhance their skills and intelligence from the very beginning of their undergraduate education. The prospective teachers should also be allowed to be successfully aware and conscious of their potential to transmit the cultural and intercultural issues to their prospective students.

However, some limitations related to the study should also be noted. The present study was conducted with the prospective EFL teachers just in one university, using quantitative research methodology. Some further studies with the students of different universities using different research techniques could be suggested.

\section{References}

Alptekin, C. (1993). Target-language culture in EFL materials. ELT Journal, 47(2), 136-143. https://doi.org/10.1093/elt/47.2.136

Alptekin, C. (2002). Towards intercultural communicative competence in ELT. ELT Journal, 56, 57-64. https://doi.org/10.1093/elt/56.1.57

Alptekin, C., \& Alptekin, M. (1984). The question of Culture: EFL teaching in non-English speaking countries. ELT Journal, 38(1), 14-20. https://doi.org/10.1093/elt/38.1.14

Ang, S., Van Dyne, L., Koh, C., Yee Ng, K., Templer, K., Tay, C., \& Chandrasekar, N. (2007). Cultural Intelligence: Its Measurement and Effects on Cultural Judgment and Decision Making, Cultural Adaptation, and Task Performance. Management and Organization Review, 3(3), 335-371. https://doi.org/10.1111/j.1740-8784.2007.00082.x

Ardila-Rey, A. (2008). Language, culture, policy, and standards in teacher preparation: Lessons from research and model practices addressing the needs of CLD children and their teachers. In M. E. Brisk (Ed.), Language, culture, and community in teacher education (pp. 331-351). New York, NY: Lawrence Erlbaum.

Atay, D., Kurt, G., Camlibel, Z., Ersin, P., \& Kaslioglu, O. (2009). The role of intercultural competence in foreign language teaching. Journal of the Faculty of Education, 10(3), 123-135.

Atkinson, D. (1999). TESOL and culture. TESOL Quarterly, 33(4), 625-654. https://doi.org/10.2307/3587880

Brislin, R., Worthley, R., \& MacNab, B. (2006). Cultural intelligence: Understanding behaviors that serve people's goals. Group and Organization Management, 31, 40-55. https://doi.org/10.1177/1059601105275262

Brown, H. D. (2007). Principles of language learning and teaching. New York, NY: Pearson Education.

Brown, S., \& Eisterhold, J. (2004). Topics in language and culture for teachers. Ann Arbor, MI: University of Michigan Press. https://doi.org/10.3998/mpub.8760

Byram, M. (1997). Teaching and Assessing Intercultural Communicative Competence. Clevedon: Multilingual Matters.

Canale, M., \& Swain, M. (1980). Theoretical bases of communicative approaches to second language teaching and testing. Applied Linguistics, 1, 1-47. https://doi.org/10.1093/applin/1.1.1 
Chomsky, N. (1965). Aspects of the Theory of Syntax. Cambridge, Massachusetts: The M.I.T. Press. https://doi.org/10.21236/AD0616323

Council of Europe. (2001). Common European Framework of Reference for Languages: Learning Teaching, Assessment. Strasbourg: Council of Europe. Retrieved from https://www.coe.int/en/web/language-policy/home

Damen, L. (1987). Culture learning: The fifth dimension in the language classroom. Reading, MA: Addison-Wesley.

Earley, P. C., \& Ang, S. (2003). Cultural intelligence: Individual interactions across cultures. Palo Alto: Stanford University Press.

Eastman, C. M. (1980). Aspects of language and culture. Novato, CA: Chandler \& Sharp.

Grittner, F. (1990). Bandwagons revisited: A perspective on movements in foreign language education. In D. W. Birckbichler (Ed.), New perspectives and new directions in foreign language education (pp. 9-43). The American Council on the Teaching of Foreign Languages Foreign Language Education Series. Lincolnwood, IL: National Textbook.

Halliday, M. A., K. (1973). Explorations in the functions of language. London: Edward Arnold.

Hofstede, G. (1984). Culture's consequences: International differences in work-related values. Beverly Hills, CA: Sage Publications.

Hymes, D. H. (1972). On communicative competence. In J. B. Pride \& J. Holmes (Eds.), Sociolinguistics: Selected readings (pp. 269-293). Harmondsworth: Penguin.

İlhan, M., \& Çetin, B. (2014). Validity and Reliability Study of the Turkish Version of the Cultural Intelligence Scale. H. U. Journal of Education, 29(2), 94-114.

Kramsch, C. (1991). Culture in language learning: A review from the United States. In K. De Bot, R. B. Ginsberg \& C. Kramsch (Eds.), Foreign language research in cross-cultural perspective (pp. 217-240). Amsterdam, The Netherlands: Benjamins. https://doi.org/10.1075/sibil.2.21kra

Kramsch, C. (1993). Context and culture in language teaching. Oxford: Oxford University Press.

Kramsch, C. J. (1998). Language and Culture. Oxford: Oxford University Press.

Kuang, J. F. (2007). Developing students' cultural awareness through foreign language teaching. Sino-US English Teaching, 4(12), 74-81.

Larsen-Freeman, D. (2000). Techniques and principles in language teaching. Oxford: Oxford University Press.

Larzén-Östermark, E. (2008). The intercultural dimension in EFL-teaching: A study of conceptions among Finland-Swedish comprehensive school teachers. Scandinavian Journal of Educational Research, 52(5), 527-547. https://doi.org/10.1080/00313830802346405

Livermore, D. (2010). Leading with Cultural Intelligence: The New Secret to Success. New York: American Management Association.

Long, F. (2001). Teaching English cultural background: Introducing the target culture in the Chinese secondary school English classes. Ph.D. Thesis, The University of Tampere.

Ng, K., Van Dyne, L., Ang, S., \& Ryan, A. (2012). Cultural intelligence: a review, reflections, and recommendations for future research. In A. Ryan, F. Leong \& F. Oswald (Eds.), Conducting Multinational Research Projects in Organizational Psychology. American Psychological Association, Washington, DC. https://doi.org/10.1037/13743-002

Sarıçoban, A., \& Çalışkan, G. (2011) The Influence of Target Culture on Language Learners. Journal of Language and Linguistics Studies, 7(1), 7-17

Sauvignon, S. J., \& Sysoyev, P. V. (2005). Cultures and comparisons: Strategies for learners. Foreign Language Annals, 38(3), 357-365. https://doi.org/10.1111/j.1944-9720.2005.tb02222.x

Schulz, R. A. (2007). The challenge of assessing cultural understanding in the context of foreign language instruction. Foreign Language Annals, 40(1), 9-26. https://doi.org/10.1111/j.1944-9720.2007.tb02851.x

Stapleton, P. (2000). Culture's role in TEFL: An attitude survey in Japan. Language, Culture and Curriculum, 13, 291-305. https://doi.org/10.1080/07908310008666605

Tang, R. (1999). The Place of "Culture" in the Foreign Language Classroom: A Reflection. The Internet TESL 
Journal, 5(8). Retrieved from http://iteslj.org/Articles/Tang-Culture.html

Tang, Y. (2006). Beyond behavior: Goals of cultural learning in the second language classroom. The Modern Language Journal, 90(1), 86-99. https://doi.org/10.1111/j.1540-4781.2006.00386.x

Valette, R. M. (1986). The culture test. In J. M. Valdes (Ed.), Culture bound (pp. 179-197). New York, NY: Cambridge University Press.

Van Dyne, L., Ang, S., \& Livermore, D. (2010). Cultural Intelligence: A Pathway for Leading in a Rapidly Globalizing World. In K. M. Hannum, B. McFeeters \& L. Booyse (Eds.), Leadership across Differences (pp. 131-138). Pfeiffer: San Francisco, CA.

Wandel, R. (2003). Teaching India in the EFL-classroom: A cultural or an intercultural approach? In M. Byram \& P. Grundy (Eds.), Context and culture in language teaching and learning (pp. 72-79). Bristol, UK: Multilingual Matters Limited. https://doi.org/10.21832/9781853596728-008

Wardhaugh, R. (2010). An Introduction to Sociolinguistics. New York: Basil Blackwell, Inc.

\section{Copyrights}

Copyright for this article is retained by the author, with first publication rights granted to the journal.

This is an open-access article distributed under the terms and conditions of the Creative Commons Attribution license (http://creativecommons.org/licenses/by/4.0/). 